\title{
Sayısal Modeller ile Taşkın Yayılım Haritasının Oluşturulması ve Risk Altında olan Alanların Belirlenmesi: Türkköse Deresi Örneği
}

\author{
Sezar Gülbaz ${ }^{1, *}$ \\ ${ }^{1}$ İstanbul Üniversitesi - Cerrahpaşa, Mühendislik Fakültesi, Inşaat Mühendisliği Bölümü, 34320, İstanbul.

\section{Özet}

Hızlı ve kontrolsüz kentleşme sebebiyle artan sel ve taşkın gibi doğal afetler hayatı olumsuz etkilemektedir. Meydana gelen kayıpların önlenebilmesi ve zararların minimuma indirilebilmesi için incelemelere zemin teșkil etmek üzere özellikle kentsel alanlardan geçen derelerin modellenmesi ve taşkın yayılım haritalarının oluşturulması gerekmektedir. Ayrıca, oluşturulan taşkın yayılım haritaları, kentsel alanlarda meydana gelen arazi kullanımı değişiklikleri dikkate alınarak güncellenmelidir. Dolayıslyla dere kenarlarında yapılan yeni yerleşimler taşkın yayılım haritaları dikkate alınarak yapılmalıdır. Ayrıca, dere kenarlarındaki mevcut yerleşim alanları da taşkın haritaları dikkate alınarak güvenli bölgelere taşınmalıdır. Bu kapsamda, taşkın debilerinin hesaplanması ve yayılım haritalarının olușturulması için yapılan çalıșmalar hayati derecede önemlidir. Bu çalıșmada, Istanbul'da bulunan Sazlıdere Havzası'nın hidrolojik modeli ve havza sinırları içerisindeki ana dere olan Türkköse Deresi'nin hidrolik modeli oluşturulmuştur. Çalışmada havza alanı, eğimi, sınırı, yükselti haritası, arazi kullanımı, toprak tipi ve dere güzergâhları WMS adlı yazılım programı kullanılarak modellenmiştir. Daha sonra, hidrolojik model için HEC-HMS ve hidrolik model için HEC-RAS programları kullanılmıştır. Oluşturulan hidrolojik model, daha önce havzada ölçülen yağış ve aklş verileri kullanılarak kalibre edilmiştir. Son olarak, 03-05 Temmuz 2005 tarihleri arasında meydana gelen șiddetli yağış kullanılarak havza üzerinde ana dere ve yan kollarda oluşan taşkın yayllım haritaları elde edilmiştir. Modelde oluşan taşkın incelenmiş ve ana derenin mansabına yakın bölgelerde su derinliğinin maksimum 8 m civarında olabileceği görülmüş̦̈̈r. Ayrıca, yerleşim alanlarından geçen ana deredeki ve yan koldaki su derinliklerinin sırası ile $6 \mathrm{~m}$ ve $4 \mathrm{~m}$ ve taşkın yayılımının $260 \mathrm{~m}$ ve $240 \mathrm{~m}$ genişlikte olduğu model sonuçlarından elde edilmiştir. Böylece, oluşturulan model ile Türkköse Deresi'nin tașkın analizi yapılmıș ve yerleșim bölgesindeki tașkından etkilenebilecek alanlar tespit edilmiștir.

\section{Developing Flood Extent Map by using Numerical Models and Determination of Areas under Flood Risk: Türkköse Stream Case}

\begin{abstract}
Due to rapid and unplanned urbanization, natural disasters such as rising floods affect the daily life. In order to prevent losses and minimize damages, it is necessary to model the streams passing through urban areas and to establish flood extent maps. In addition, the generated flood extent maps should be updated taking into account the changes in land use occurring in urban areas. Moreover, new settlements near the streams should be made by considering the flood extent maps. Moreover, existing residential areas near the streams should also be resettled to safe areas, taking into account flood extent maps. In this context, studies on the calculation of flood flows and the development of flood extent maps are of vital importance. In this study, the hydrological model of the Sazlidere Watershed in Istanbul and the hydraulic model of the Türkköse Stream, which is the main stream within the basin boundaries, were generated. In the study, watershed area, slope and boundary, elevation map, land use, soil type and stream routes were modeled by using the WMS software program. The HEC-HMS software program for hydrological model and the HEC-RAS software program for hydraulic model were used. The hydrological model was calibrated by using rainfall and flow rate data previously measured in the watershed. Finally, flood extent maps generated on the main stream and side branches on the watershed were obtained by using heavy rainfall between 03 and 05 July 2005. The floods in the model were examined and it was observed that the depth of the water in the areas close to the downstream of the main stream could be around $8 \mathrm{~m}$. In addition, it was determined from the model results that the water depths in the main stream and on the side branch passing through the settlement areas were $6 \mathrm{~m}$ and $4 \mathrm{~m}$, respectively, and the flood extent widths were $260 \mathrm{~m}$ and $240 \mathrm{~m}$, respectively. Thus, the flood analysis of the Türkköse Stream was carried out with the described model and the areas affected by the flood in the settlement area were determined.
\end{abstract}

\section{$\underline{\text { Keywords }}$}

Türkköse Stream, Flood, Flood Extent Map, WMS, HEC-HMS, HEC-RAS 


\section{Giriş}

Taşkınlar, akarsu yataklarında suyun debisinin artması sonucunda akarsuyun çevresindeki yaşamı olumsuz etkileyen doğal afetlerdir (Mahmood Siddiqui vd. 2011). Taşkınlar ani olarak ve belirli periyotlarda meydana gelen (Subyani 2009) ve yıkım gücü fazla olan, can ve mal kaybına neden olan doğal afetler arasında yer almaktadır (Ibrahim vd. 2017). Taşkınların oluşmasında etkili olan temel sebepler meteorolojik, topoğrafik ve jeomorfolojik faktörlerdir (Şen vd. 2013; Cai vd. 2016). Fakat doğal sebeplerin yanında insanların doğaya müdahalesi de taşkınların oluşmasında önemli rol oynamaktadır (Qin vd. 2015). Gelişen sanayi ve teknoloji ile birlikte şehirlerdeki nüfus artmaktadır. Artan nüfus ile birlikte kentleşme artmaktadır. Kentleşmenin artması ile birlikte kontrolsüz yapılaşma akarsu yataklarına müdahale etmektedir. Örneğin, yapılaşmanın özellikle dere güzergahlarında yapılması sonucu dere kesit alanı daralmakta ve taşkınlar oluşmaktadır. Her yıl milyonlarca canlıyı etkileyerek ölümlere neden olmakta, çevre tahribatı yaparak ekonomiyi olumsuz yönde etkilemektedir. Dünyanın çeşitli yerlerinde taşkınlar nedeni ile milyonlarca canlı yaşamını yitirmekte ve maddi kayıplar yaşanmaktadır (Uddin vd. 2013). Pakistan, Hindistan ve Çin 2010 yılında, Avustralya 2010 2011 yılları arasında taşkınlardan ciddi oranda etkilenmiştir. Bir yılda bir ülkede akarsu taşkını sonucu oluşan maksimum zarar 51 milyar dolar ile 2010 yılında Çin'de görülmüştür. 2010 yılında Pakistan'da muson taşkınları sonucu neredeyse 2000 kişi hayatını kaybetmiştir (Kundzewicz vd. 2014). Ülkemizde ise durum benzer şekildedir. Batı Karadeniz'de meydana gelen sel afetlerinde 1998 yılında 2 milyondan fazla kişi etkilenmiş, 30'dan fazla can kaybı meydana gelmiş, 151 dere ve ırmak yatağı taşmış ve 478 ev tamamen su altında kalmıştır. Doğu Karadeniz bölgesinde de sıkça yaşanan taşkın ve beraberinde meydana gelen heyelan olayları ciddi can ve mal kayıplarına neden olmaktadır (Oğuz vd. 2016a). Ege kıyılarını etkisi altına alan şiddetli yağışlar ile 61 kişi hayatını kaybetmiş ve maddi hasar meydana gelmiştir (Kömüşçü vd. 1998). 8-12 Eylül 2009 tarihleri arasında İstanbul'da yaşanan sel felaketi akıllarda Ayamama taşkını olarak yer etmiştir. Bu taşkında 32 kişi hayatını kaybetmiş, 3816 konut ve 1490 işyeri zarar görmüştür (Kömüşçü vd. 2011). Bu verilere baktığımızda taşkınların kontrol altına alınmasının ne kadar zaruri olduğu açıkça anlaşılmaktadır. Taşkınların kontrol altına alınabilmesi için taşkın bölgelerinin belirlenmesi gerekmektedir. Bu kapsamda, taşkın bölgelerinin belirlenmesi için model çalışmalarına ihtiyaç duyulmaktadır. Literatürde çeşitli bölgeler için taşkın yayılım haritalarının oluşturulmasına yönelik çalışmalar bulunmaktadır (Romali vd. 2018; Hoseinil vd. 2017). Fakat taşkın yayılım haritalarının tehlike altında olan bütün bölgeler için ayrı ayrı hazırlanması gerekmektedir. Dolayısıyla risk altında olan her bölge için taşkın yayılım haritalarının hazırlanması, oluşabilecek risklerin öngörülerek önlem alınması büyük önem arz etmektedir (Apel 2008).

Taşkınları araştırmak ve önlemek amacıyla yapılan çalışmalarda bilgisayar programlarının kullanımı fayda sağlamaktadır (Liu vd. 2015; Merwade vd. 2008).Bu kapsamda, Oğuz vd. (2016b) havza çalışmalarında kullanımı her geçen gün daha da artan Coğrafi Bilgi Sistemi (CBS) tekniklerini Artvin ilinin taşkın risk alanlarını belirlemek için kullanmışlardır. Ayrıca, Coğrafi Bilgi Sistemlerinin hidrolojik ve hidrolik modellemeler ile birlikte kullanılmasının faydalı olduğu birçok araştırmacı tarafından açıkça belirtilmiştir (Elçi vd. 2017; Patel vd. 2013; Jayakrishnan vd. 2005). WMS (Watershed Modeling System) programı hidrolojik ve hidrolik programlar ile entegre çalışan, CBS uyumlu ve literatürde kullanılan güvenilir bir programdır. Hoseinil vd. (2017), WMS programını kullanarak Khuzestan eyaletindeki Simili havzasında sel modellemesi yapmıştır. Örneğin, Soliman vd. (2015) Yemen' de bulunan Wadi Hadramawt'da WMS ile hidrolojik analizler yapmış ve çözüm önerileri sunmuştur. Kong vd. (2017), Çin'deki yüksek konsantrasyonlu Yellow Nehri’nin çevresel etkilerini araştırmış ve çözüm önerileri sunmuştur.

HEC-HMS (Hydrologic Engineering Center-Hydrologic Modeling System) programı ise havzaya ait hidrolojik modelleme yapan, literatürde yer almış güvenilir bir programdır. HEC-HMS programı kullanılarak Wadi Ressoul Havzası için modelleme çalışması yapılmış ve modelin verimliliği araştırılmıştır (Skhakhfa ve Querdachi 2016). Elkhrancy (2018), CBS temelli çalışarak Necran Vadisi için taşkın analizi yapmıştır. Bu çalışmada HEC-HMS, HEC-GeoRAS modelleri oluşturulmuştur. Amazon Nehir Havzası modeli HEC-HMS ile Beighley vd. (2009) tarafından yapılmıştır. Ayrıca, Tayvan'da tayfun sebebiyle oluşacak akışı modellemek için HEC-HMS uygulaması yapılarak 90 yıllık bir geri dönüş periyodu gözlemlenmiştir (Chen ve Huang 2013). Ivan Kasırgası'nın Jamaica Hope Nehir Havası üzerinde sebep olacağı akışı gözlemleyebilmek için HEC-HMS üzerinde model kurulmuştur (Mandal vd. 2016).

HEC-RAS (Hydrologic Engineering Center-River Analysis System) programı modelleme yapan, literatürde yer almış güvenilir bir programdır. Bu kapsamda literatürde çeşitli çalışılmalara rastlanılmaktadır (Özcan vd. 2011; Özcan, 2008). Logah vd. (2017) Volta Nehri için yaptıkları çalışmada bölgedeki ovaların jeomorfolojisini başarılı şekilde haritalandırmış, hidrodinamik model oluşturmuş ve HEC-RAS modelini kullanarak taşkın seviyesi tahminlerinde bulunmuşlardır. Yapılan başka bir çalışmada Malezya Segamat Şehri için HEC-RAS yazılımı kullanılarak bir taşkın modeli oluşturulmuş ve 2011 yılında bölgede gerçekleşerek sele sebep olan yağış verileri modele girildiğinde taşkın derinliği \%91'in üzerinde bir doğruluk payı ile tespit edilmiştir (Romali vd. 2018). Hanmaiahgari vd. (2018) HEC-RAS programından yararlanarak, Sakuma Barajı'nda meydana gelebilecek sedimantasyon hareketini incelemişlerdir. Moreno ve Fontalvo (2017) Frio Nehri (Texas)'nin hidrolik modellemesini HEC-RAS programında çalışırken; hidrolojik modelini HEC-HMS programında oluşturmuştur. Mahmood Siddiqui vd. (2011) HEC-RAS programını kullanarak Pakistan'da hidrolik bir havza modeli çıkarmışlardır. Bu çalışmalarında WMS programında model altlığı oluşturarak çalışmışlardır. Bir başka çalışmada ise Khalfallah ve Saidi (2018) Tunus'ta Majerda Nehri'nin taşkın risk haritasını HEC-RAS programını kullanarak oluşturmuşlardır. 
Oluşturulan bu harita, taşkın yatak su seviyesinin tahmin edilmesinde kullanılmıştır. Boyraz vd. (2015) WMS programı kullanarak Kocaeli Çayırova Havzası için yaptıkları çalışmada hidrodinamik model oluşturmuş, bölgede özellikle Gebze Teknik Üniversitesi kampüs binalarına ulaşan suların taşkın riskinin yüksek olduğu sonucuna varmış ve çözüm önerisi olarak havzadaki tüm menfez, köprü ve kanalların temizlenmesi ile beraber menfez kesitlerinin büyültülmesi gerektiği kanısına varmışlardır. Ayrıca bu tür çalışmaların Türkiye'deki diğer bölgeler içinde yapılması gerektiği vurgulanmıştır (Boyraz vd. 2015).

Bu çalışma kapsamında Sazlıdere Havzası’nın Hidrolojik modeli ve havzada bulunan Türkköse Deresi’nin hidrolik modeli oluşturulmuştur. Derenin herhangi bir taşkın anında su altında kalma olasılı̆̆ı olan alanlar belirlenip olası can ve mal kayıplarının engellenmesi hedeflenmiştir. Bu hedefe ulaşmak için HEC-RAS, HEC-HMS, WMS programlarından faydalanılmıştır. Modelleme kapsamında, WMS programıyla havzanın coğrafi bilgileri elde edilmiştir. HEC-HMS programıyla hidrolojik model oluşturularak daha önce ölçülen yağış değerleri (Gülbaz ve Kazezyılmaz-Alhan 2013) programa girilmiştir. Hidrolojik model ile yağış anında oluşacak debi hesaplanmıştır. Hesaplanan debi havzada ölçülen debi (Gülbaz ve Kazezyılmaz-Alhan 2013) ile karşılaştırılmış ve model kalibre edilmiştir. HEC-RAS programıyla da hidrolik model oluşturulmuş ve derede oluşan akış modellenmiştir. Kalibre edilen hidrolojik modele geçmiş yıllarda (Temmuz 2005) meydana gelen şiddetli bir yağış hiyetografi girilmiş ve havzanın çıkış noktasında debi hesaplanmıştır. HEC-HMS programı ile oluşturulan hidrolojik model ile hesaplanan debi HEC-RAS programına girilmiştir. Daha sonra HEC-RAS programından elde edilen hesaplamalar tekrar WMS programına alınarak taşkın yayılım haritaları elde edilmiştir. Böylece tehlike altında olan bölgeler tespit edilmiştir.

\section{Materyal ve Yöntem}

\subsection{WMS, HEC-HMS ve HEC-RAS}

$\mathrm{Bu}$ çalışma kapsamında, WMS, HEC-HMS ve HEC-RAS programları kullanılmıştır. HEC-HMS ve HEC-RAS programları WMS programının içerinde hidrolojik ve hidrolik modüllerin altında yer almakta ve entegre çalışmaktadır. WMS, akarsu havzalarının ve derelerin hidrolojik ve hidrolik hesaplamalarını yapan programlar ile entegre çalışma özelliğine sahiptir. WMS'de modeller kurulurken CBS ile gerekli veriler uydudan temin edilmektedir. Bu sayede havzaya ait alan, eğim, maksimum akış mesafesi, ortalama yükseklik gibi önemli parametreler otomatik olarak hesaplanmaktadır. Ayrıca arazi kullanımı ve toprak tipi değerleri bu şekilde elde edilmektedir. Elde edilen veriler Dijital Yükselti Modelleri (DEM) ve Üçgen Düzensiz Ağlar (TIN) şeklinde hazırlanmakta ve hidrolojik-hidrolik model altlıklarında kullanılmaktadır. Akarsu havzalarındaki akış yönleri ile dere güzergahlarının belirlenmesi için WMS içerisinde TOPAZ (Topoğrafik Penatrasyon) Programı geliştirilmiştir. TOPAZ, Amerika Birleşik Devletleri Tarım Bakanlığı'nın bir birimi olan, Tarımsal Araştırma Servisi tarafından geliştirilmiştir. Bununla birlikte WMS içerisinde yer alan hidrolojik modülde HEC-1, HEC-HMS, SWMM, TR-20, TR-55, NSS, Rational, MODRAT, OC Rational, OC Hydrograph ve HSP programları yer almaktadır. Ayrıca, hidrolik modülde de HEC-RAS, QGIS, SMPDBK, SWMM, SWMM Sanitary ve HY-12 programları bulunmaktadır.

HEC-HMS herhangi bir akarsu havzasının hidrolojik süreçlerini tam olarak model haline getirebilmek amacıyla ABD Ordusu Mühendisleri Birliği (USACE) Hidroloji Mühendisliği Merkezi tarafından geliştirmiş olup günümüzde de dünya çapında yapılan araştırma ve testlerde yaygın olarak kullanılmaktadır (Scharffenber 2010). Yağış-akış arasındaki ilişki sürecini modelleyebilmek için HEC-HMS kullanılan başarılı bir programdır. Havza, alt havza, ana dere, yan kollar, birleşme noktaları, rezervuarlar ve kaynaklar ile akarsu çıkış noktaları temel hidrolojik elemanlardır. HEC-HMS, sızma analizi ve birim hidrografların çıkarılması gibi pek çok konvansiyonel hidrolojik analiz prosedürleri ile evapotranspirasyon, kar erimesi, zemindeki su muhtevası gibi parametreleri içermektedir.

HEC-RAS, ABD Ordusu Mühendisleri Birliği Su Kaynakları Enstitüsü tarafından doğal veya inşaat faaliyetleri sonucu oluşturulmuş bir akarsu modelleme programıdır. HEC-RAS, akarsuların bir ve/veya iki boyutlu hidrolik hesaplarını yaparak, akarsuyun modellenmesi amacıyla tasarlanmıştır. İlk olarak 1995 yılında piyasaya çıkmış olan bu programda tek boyutlu su yüzey profilleri ile düzenli akışlar hesaplanmıştır. Daha sonraları kademeli olarak değişken bir profil gösteren, düzensiz akış profilleri ile karışık profillerin modellenmesi sağlanmıştır. Son olarak, su kalitesi analizleri ile sediman taşınım hesaplarının yapılabilmesi için program geliştirilerek kullanılmıştır. HEC-RAS programında kanal geometrisi ve akımın hidrolik analizleri için kullanılan bir takım parametrelerden faydalanılmaktadır.

\section{2. Çalışma Alanı: Sazlıdere Havzası}

Sazlıdere Havzası İstanbul'un Avrupa yakasında, Durusu (Terkos) Gölü’nün güneydoğusunda, Küçükçekmece Gölü’nün kuzeydoğusunda ve İstanbul Büyükşehir Belediyesi'nin sınırları içerisinde Şekil 1'de görüldüğü gibi yer almaktadır. Sazlıdere Havzası yağış alanı, doğuda Küçükçekmece Gölü’ne dökülen Hasanoğlu (Balıklı) Deresi’nin, kuzeyde Terkos Gölü’nün, batıda ise yine Küçükçekmece Gölü’ne dökülen Ispartakule (Hadımköy) Deresi'nin yağış alanları ile çevrilidir. Havzanın denizden olan yüksekliği rezervuarların olduğu yerlerde 35-40 m civarında olup kuzey ve güneydeki topoğrafik sinırlarda 180 m’ye ulaşmaktadır. 
Sazlıdere Havzası'nda toplanan sular, havza çıkışında bulunan Sazlıdere Barajı'nda toplanmaktadır. Sazlıdere Barajı TEM şehirlerarası otoyolunun kuzeyinde, Sazlıdere üzerinde ve Küçükçekmece Gölü membasının yaklaşık 6 km uzağında kurulmuştur.

Havza doğu-batı yönünde 20 km uzunluğa, kuzey-güney yönünde ise 9 km genişliğe sahiptir. İstanbul'un önemli içme suyu havzalarından biri olan Sazlıdere Havzası'ndaki Sazlıdere Barajı yıllık 55 milyon $\mathrm{m}^{3}$ su ile İstanbul'un su ihtiyacını karşılamaya katkı sağlamaktadır. Sazlıdere Havzası'nın toplam drenaj alanı $165 \mathrm{~km}^{2}$ 'dir. Bu alanın \% 58'ini tarım arazileri ve meralar, \% 18.22'sini yerleşim ve sanayi alanları, \% 18'ini ormanlık alanlar ve \% 5.78'ini baraj alanı oluşturmaktadır (Birpınar vd. 2006; Akça 2005). Ancak havza üzerinde doğrudan etkili olan çok büyük projeler ve buna bağlı olarak, yoğun bir nüfus artış potansiyeli bulunmaktadır. İstanbul Havalimanı, Yavuz Sultan Selim Köprüsü ve çevre yolları, Karadeniz'i Marmara Denizi’ne bağlayan, yeni bir boğaz geçişi olan Kanal İstanbul projesi, yapılmakta olan ve yapılması planlanan büyük projelerdir. Bu projeler ile birlikte havzada büyük oranda kentleşme ve nüfus artışı beklenmektedir. Bu durum havzanın hidrolojik yapısını derin bir şekilde etkileyecektir. Bu nedenle, bölgenin taşkın tehlikesi açısından incelenmesi büyük önem arz etmektedir.

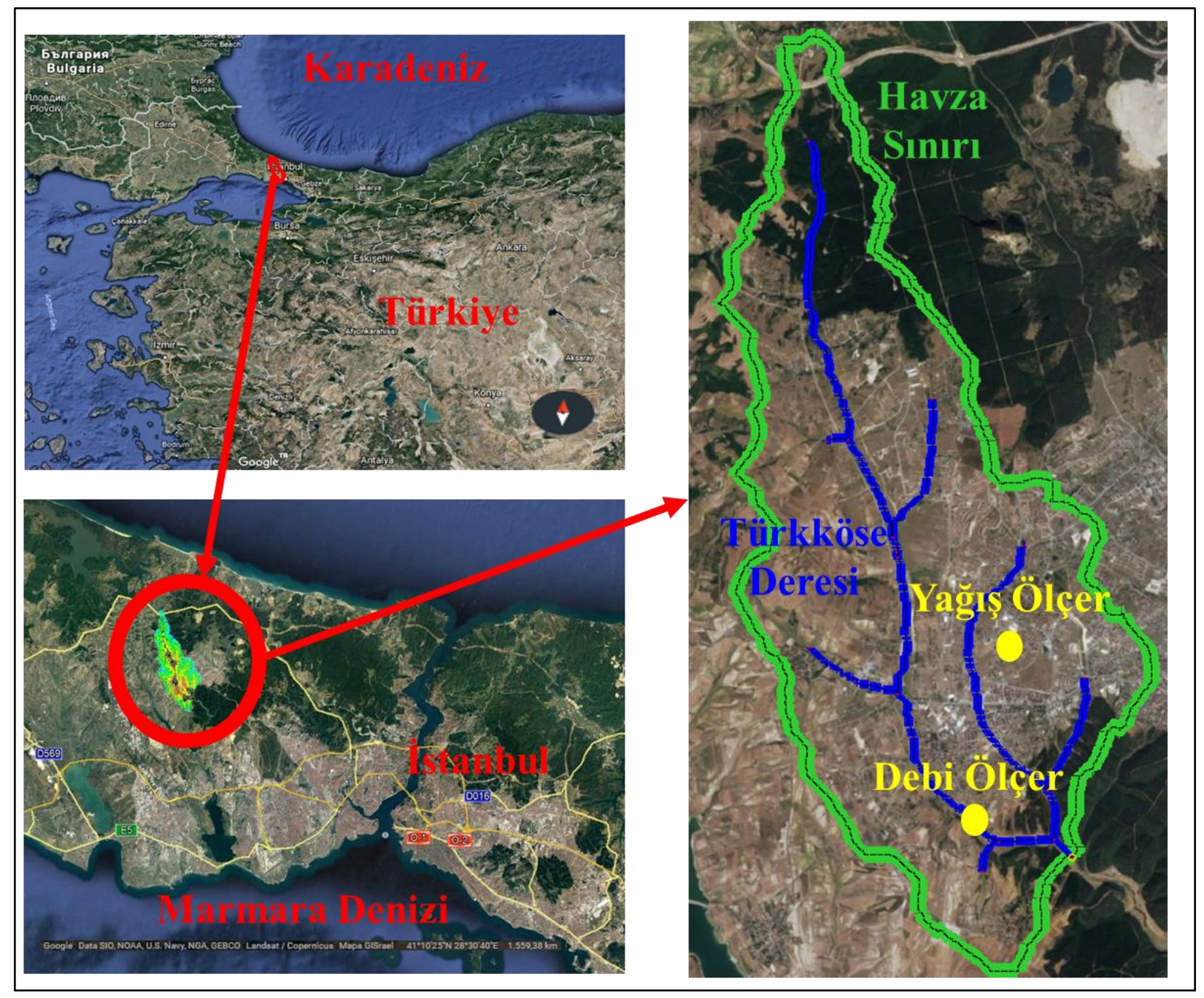

Şekil 1: Sazlıdere Havzasının genel görümümü (Google Earth, Data SIO NOAA U.S. Navy NGA GEBCO, Image Landsat/Copernicus)

\subsection{Model Oluşturulması}

Bu çalışmada Sazlıdere Havzası içerinde bulunan Türkköse Deresi’nin su topladığı alan modellenmiştir. Bu alan Sazlıdere Havzası'nın yaklaşık dörtte birlik bölümünü $\left(36 \mathrm{~km}^{2}\right)$ oluşturmaktadır. Modelleme aşamasında ilk olarak, WMS programından Türkköse Deresi Havzası alanına ait topoğrafik harita elde edilmiştir. Modelde proje alanı için "STRM (Shuttle Radar TopographyMission) Worldwide Elevation Data (3-arc-second Resolution)" dijital uydu haritasından alınan10 m çözünürlüğe sahip DEM haritası (Şekil 2a) kullanılmıştır. Ayrıca, Şekil 2c'de görülen arazi kullanımı haritası (CORINE,2012 - Coordination of Information on the Environment) ve Şekil 2d'de görülen toprak tipi haritası (ESDAC, 2015 - European Soil Data Centre) WMS programında kullanılmıştır. 
Bu haritalar SCS-CN (Toprak Koruma Kurumu - Eğri Numarası) yağış-akış metodu için altlık oluşturmuştur. Bu metot için gerekli olan arazi kullanımları ile hidrolojik toprak gruplarına ait Tablo 1'de görülen CN (Eğri Numarası) değerleri WMS programında kullanılmıştır. Havza için ortalama (ağırlıklı) CN değeri havzadaki arazi kullanımı, hidrolojik toprak grupları ve bu değerlerin havzada kapladığı alanlar dikkate alınarak WMS programı içerisinde hesaplanmış ve 59 olarak bulunmuştur. Ortalama CN değerinin kullanıldığı SCS-CN yağış akış modeli aşağıda verilmiştir (SCS 1975):

$$
\begin{aligned}
& C N_{\text {Ortalama }}=\frac{\sum_{i=1}^{n}\left(C N_{i} * A_{i}\right)}{\sum_{i=1}^{n} A_{i}} \\
& S=\frac{25400}{C N}-254 \\
& R=\frac{(P-0.2 S)^{2}}{P+0.8 S}
\end{aligned}
$$

Bu denklemlerde, $C N_{\text {ortalama }}$ ağırlıklı Eğri Numarası, $C N_{i}$ her bir arazi kullanımı için belirlenen Eğri Numarası, $A_{i}$ arazi alanı $\left(L^{2}\right), S$ toprak tarafından tutulan su miktarı $(L), P$ yağış miktarı $(L), R$ artık yağış miktarı (yüzeysel akış miktarı) $(L)$

\begin{tabular}{|c|c|c|c|c|c|c|}
\hline \multirow[t]{2}{*}{ Kodu } & \multirow[t]{2}{*}{ Arazi Kullanımı Örtüsü } & \multicolumn{4}{|c|}{$\begin{array}{c}\text { Hidrolojik Toprak Gruplarına Göre } \\
\text { Eğri Numarası Değerleri } \\
\text { CN }\end{array}$} & \multirow[t]{2}{*}{$\begin{array}{c}\text { Yüzey } \\
\text { Maning } \\
\text { Katsayısı }\end{array}$} \\
\hline & & $\mathbf{A}$ & $\mathbf{B}$ & $\mathbf{C}$ & D & \\
\hline ID 111 & Sürekli kentsel yap1 & 57 & 72 & 81 & 86 & 0.025 \\
\hline ID 112 & Süreksiz kentsel yap1 & 63 & 77 & 85 & 88 & 0.040 \\
\hline ID 122 & Karayolu ve demiryolu ağları ve ilgili arazi & 83 & 89 & 92 & 93 & 0.025 \\
\hline ID 133 & Şantiyeler & 80 & 83 & 87 & 90 & 0.025 \\
\hline ID 211 & Sulanmayan ekilebilir arazi & 67 & 77 & 83 & 87 & 0.140 \\
\hline ID 231 & Meralar & 49 & 69 & 79 & 84 & 0.140 \\
\hline ID 242 & Karmaşık ekim alanları & 62 & 73 & 81 & 84 & 0.100 \\
\hline ID 243 & Tarım alanı, doğal bitki örtülü arazi & 62 & 73 & 81 & 84 & 0.150 \\
\hline ID 311 & Geniş yapraklı orman & 45 & 66 & 77 & 83 & 0.170 \\
\hline ID 313 & Karışık orman & 36 & 60 & 73 & 79 & 0.192 \\
\hline
\end{tabular}
olarak tanımlanmıştır.

Tablo 1: Hidrolojik Toprak Gruplarına Göre CN(Eğri Numarası) Değerleri (CORINE 2012)

Modelleme aşamasının ikinci bölümünde WMS ile elde edilen havza model altlığı ve bilgileri HEC-HMS programına WMS'den aktarılmıştır. HEC-HMS ile kurulan hidrolojik modelin çalışabilmesi için 3 temel başlığa ihtiyaç duyulmaktadır. İhtiyaç duyulan 3 temel bölüm; havza bilgilerinin yer aldığ havza modeli, yağış tipinin tanımlandığ1 meteorolojik model ve tarih verilerinin tanımlandığ kontrol bölümden oluşmaktadır. Havzada sızma hesaplanmasında SCS Eğri Numarası, akış hesaplanmasında SCS Birim hidrograf yöntemi ve kanalda akış ötelemesi için kinematik dalga metodu seçilmiştir. Bununla birlikte, havzaya yerleştirilen yağış ölçerden alınan yağış yükseklikleri hiyetografa çevrilmiştir. Ölçülen yağış şiddeti ve akış değerleri modelin kalibrasyonunda ve doğrulanmasında kullanılmıştır. Daha sonra, geçmiş yıllarda meydana gelen şiddetli bir yağış örneği Meteoroloji Genel Müdürlüğü Florya Meteoroloji İstasyonu'ndan alınmış ve modelde kullanılmıştır. Ayrıca, sahada ölçülen taban akışı $0.47 \mathrm{~m}^{3} / \mathrm{sn}$ olarak modelde kullanılmıştır. Bununla birlikte geçirimsiz yüzey alanı yüzdesi \%20 olarak tanımlanmıştır. Oluşturulan HEC-HMS modeli Şekil 4a'da görülmektedir.

Modelleme aşamasının üçüncü bölümünde, WMS programında oluşturulan model altlık olarak HEC-RAS programında da kullanılmış ve hidrolik model elde edilmiştir. Hidrolik modelde DEM haritasından üretilen TIN modeli kullanılmıştır. Türkköse Deresi'nin genişliği dikkate alınarak akarsu morfolojisine uygun bir şekilde dere en kesitleri belirlenmiş ve dere için Manning pürüzlülük katsayısı değerleri 0.045 ve dere kenarları için 0.050 (Chow 1959) olarak modele girilmiştir. WMS model altığındaki bu çalışmaların sonrasında model HEC-RAS programı üzerine aktarılarak suyun kanal içindeki hidrolik hesabı kararlı akım kabulü yapılarak oluşturulmuştur. Akım rejiminin kritik altından kritik üstüne veya kritik üstünden kritik altına geçmesi durumlarında program tarafından kullanılan karışık akım rejimi (Ardıçlıoğlu 2017) opsiyonu programda kullanılmıştır. Oluşturulan HEC-RAS modeli Şekil 4-b'de görülmektedir.

Modelleme aşamasının son kısmında Florya Meteoroloji İstasyonu'ndan alınan şiddetli yağış kullanılarak hidrolojik model ile hesaplanan debi değeri HEC-RAS programında kullanılmış ve daha sonra WMS programına aktarılmıştır. WMS modelinde 3-5 Temmuz 2005 yılında meydana gelen şiddetli yağış için taşkın yayılım haritaları elde edilmiştir. Ayrıca, modelleme bölümünde yer alan bilgiler Şekil 3 'te model akış şemasında verilmiştir. 


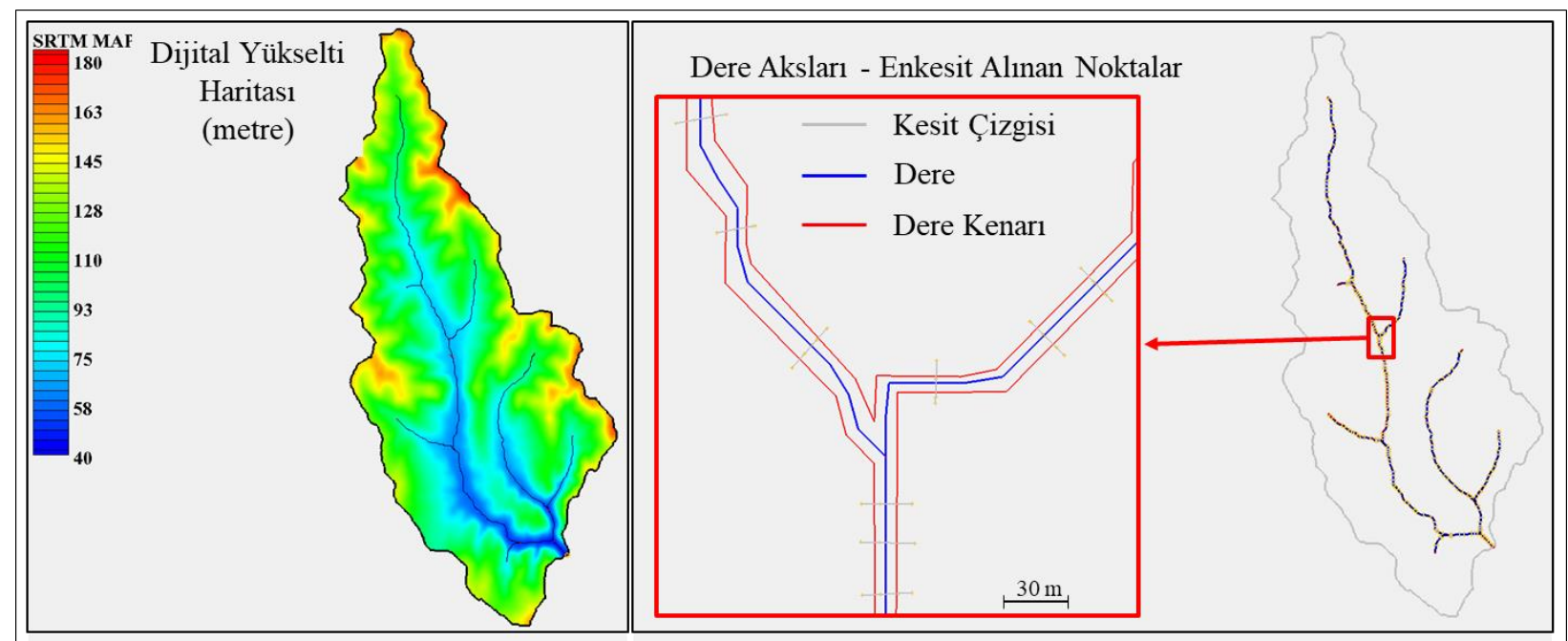

(a)

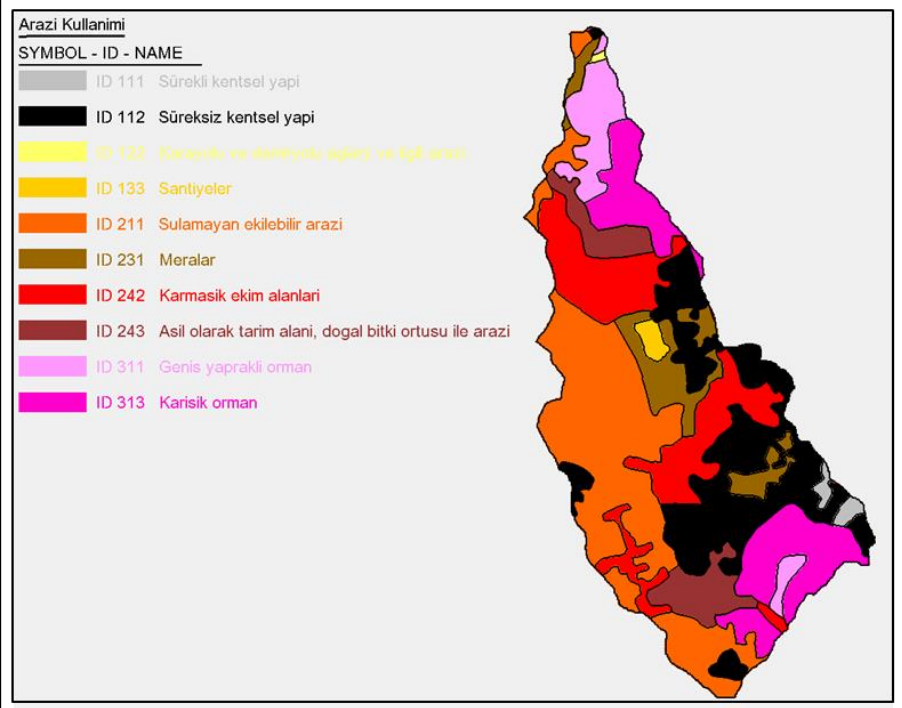

(c) (b)

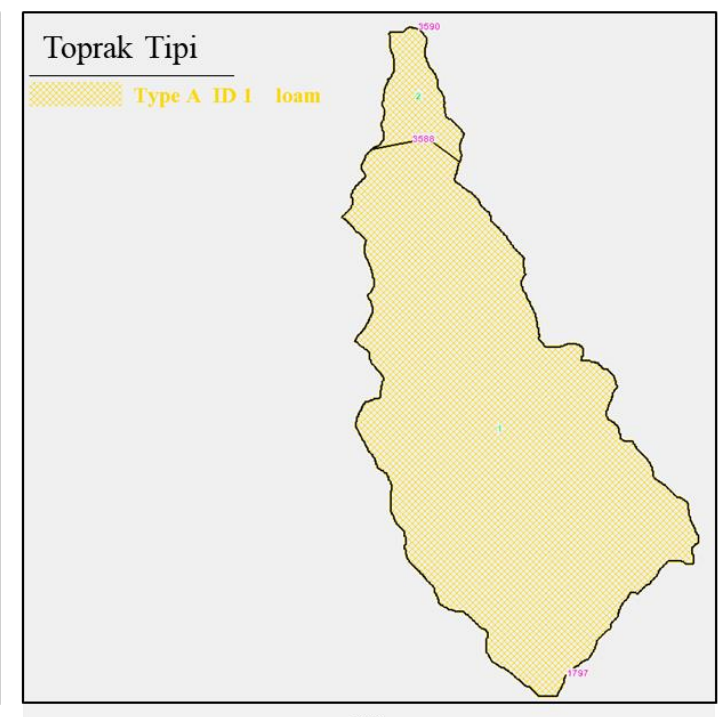

(d)

Şekil 2: WMS programında oluşturulan modele ait haritalar; (a) dijital yükselti haritası (STRM

Worldwide Elevation Data), (b) dere aksları-en kesit alınan noktalar, (c) arazi kullanımı haritası altığı (CORINE 2012), (d) toprak tipi haritası altığı (ESDAC 2015) 


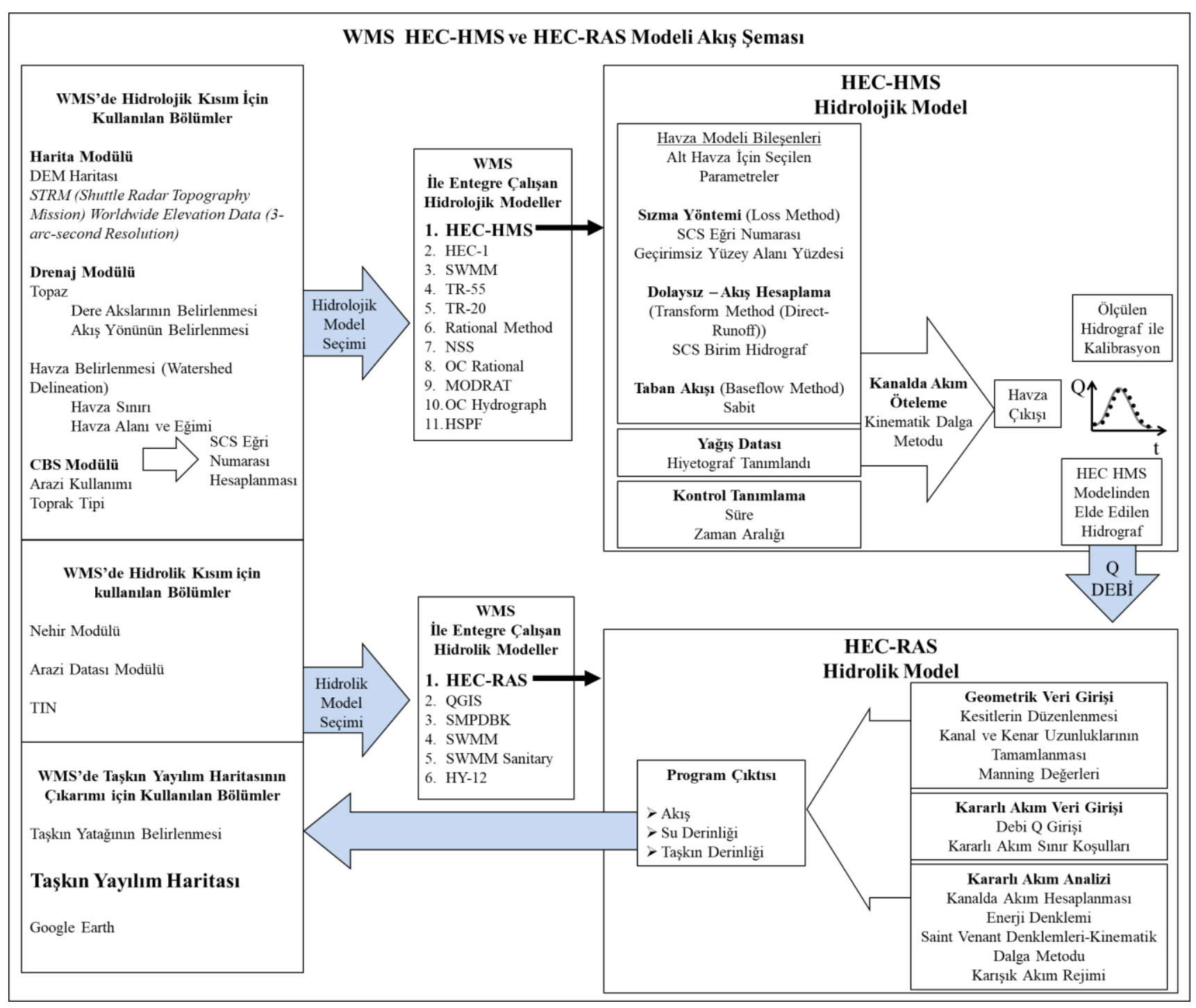

Şekil 3: WMS, HEC-HMS ve HEC-RAS modeli akış şeması 


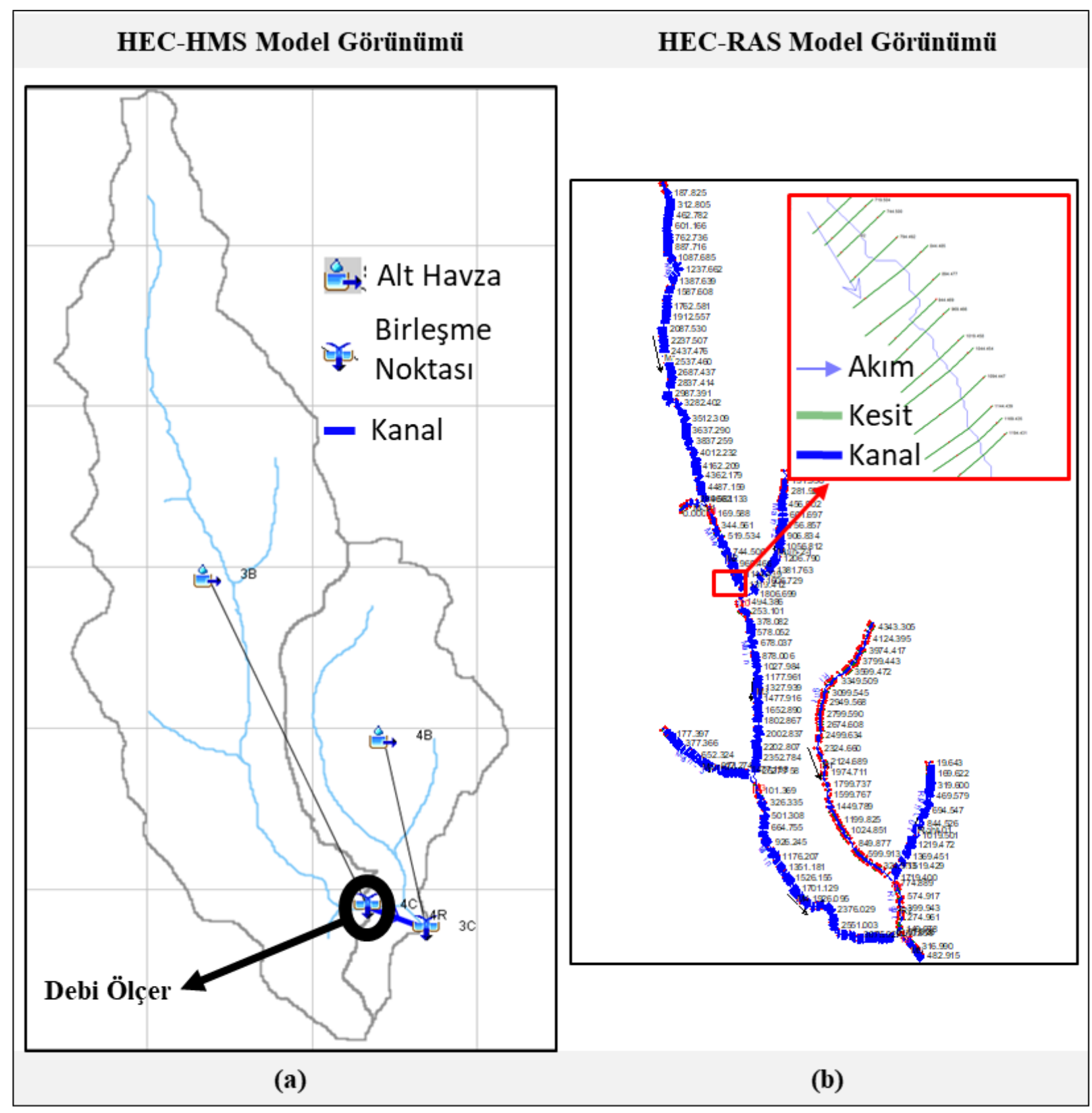

Şekil 4: HEC-HMS ve HEC-RAS model görünümleri

\subsection{Model Kalibrasyonu}

HEC-HMS programı ile oluşturulan hidrolojik modelin kalibrasyonu için sahada 14-17 Şubat 2010 tarihleri arasında ölçülen 4 günlük yağış ve bu yağış sonucu oluşan akış değerleri kullanılmıştır. Çalışmada yağış-akış modeli olarak SCSCN metodu kullanılmış ve bu metot için gerekli olan arazi kullanımı, toprak tipi haritası ve hidrolojik toprak grupları gibi altlıklar WMS programına tanımlanmıştır. Böylece, alt havzalar için CN değeri hesaplanmıştır. WMS programında hesaplanan CN değeri HEC-HMS programına aktarılarak sızma ve dolaysız akış hesaplarında SCS-CN ve SCS Birim Hidrograf metotlarında kullanılmıştır. Ayrıca geçirimsiz yüzey alanı programa girilmiştir. HEC-HMS programı ile oluşturulan hidrolojik model ile debi ölçümü yapılmış ve ölçülen değerler deney sonuçları kullanılarak kalibre edilmiştir. Daha sonra, kalibre edilmiş hidrodinamik modelin doğrulanması için 06-09 Mart 2010 tarihlerinde meydana gelen 4 günlük yağış ve akış değerleri kullanılmıştır. Çalışmanın bu aşamasında kalibre edilmiş parametrelerin bulunduğu modele sadece 06-09 Mart 2010 tarihlerinde yağan yağış şiddeti girilmiş, model çalıştırılarak yüzeysel akış için sonuçlar elde edilmiştir. Ve model sonuçları ile deney sonuçlarının birbirine oldukça yakın sonuçlar verdiği gözlemlenmiştir. 


\section{Bulgular}

\subsection{Model Kalibrasyonu ve Doğrulamasına ait Bulgular}

Çalışmanın bu bölümünde, HEC-HMS programı kullanılarak havzanın çıkış noktasında oluşan debi değerleri hesaplanmıştır. Hesaplanan değerler ölçülen değerler ile kalibre edilmiştir. Elde edilen sonuçlar karşılaştırıldığında HECHMS ile hesaplanan pik debi 14-17 Şubat 2010 tarihleri arasında meydana gelen yağgş için $3.511 \mathrm{~m}^{3} / \mathrm{saniye} \mathrm{olarak}$ bulunmuştur. $\mathrm{Bu}$ değer dere üzerinde $3.511 \mathrm{~m}^{3} /$ saniye olarak ölçülmüştür. Bu durumda pik debi için mutlak yüzde hata hesaplandığında ölçülen değer ile hesaplanan değer arasında \% 0.005 hata olduğu görülmüştür. Ayrıca, Şekil 5 'te yağış şiddeti siyah kolonlar ile ölçülen debi değerleri gri noktalar ile ve hesaplanan debi değerleri kırmızı çizgi ile gösterilmiştir. Ölçülen ve hesaplanan hidrograflar karşılaştırılmış ve Belirleme Katsayısı $\left(\mathrm{R}^{2}\right)$ hesaplanmıştır. Hesaplanan belirleme katsayısı kalibrasyonda kullanılan yağış için 0.787 olarak bulunmuştur. Bu değer ile hesaplanan ve ölçülen hidrografın birbirine yakın sonuç verdiği görülmektedir. Aynı şekilde, 06-09 Mart 2010 tarihlerinde meydana gelen 4 günlük yağış ve akış değerleri kullanılmış ve model doğrulanmıştır. Elde edilen sonuçlar Tablo 2'de gösterilmiştir. Ayrıca, doğrulama için kullanılan yağış-akış sonuçlarına ait hesaplanan ve ölçülen hiyetograf ve hidrograflar Şekil 6'da görülmektedir.

Tablo 2: Hesaplanan ve ölçülen debi değerleri ve hata oranları

\begin{tabular}{|l|c|c|c|c|}
\hline \multicolumn{1}{|c|}{ Yağış } & $\begin{array}{c}\text { HEC-HMS'de } \\
\text { Hesaplanan Pik Debi } \\
\left(\mathbf{m}^{\mathbf{3}} / \mathbf{s n}\right)\end{array}$ & $\begin{array}{c}\text { Ölçülen Pik Debi } \\
\left(\mathbf{m}^{\mathbf{3}} / \mathbf{s n}\right)\end{array}$ & $\begin{array}{c}\text { Pik Debi için } \\
\text { Mutlak Yüzde Hata } \\
(\mathbf{\%})\end{array}$ & $\begin{array}{c}\text { Belirleme } \\
\text { KatsayıSI } \\
\left(\mathbf{R}^{\mathbf{2}}\right)\end{array}$ \\
\hline $\begin{array}{l}\text { Kalibrasyon } \\
\text { 14-17 SSubat 2010 }\end{array}$ & 3.511 & 3.509 & 0.005 & 0.787 \\
\hline $\begin{array}{l}\text { Doğrulama } \\
\text { 06-09 Mart 2010 }\end{array}$ & 5.218 & 5.515 & 5.377 & 0.658 \\
\hline
\end{tabular}

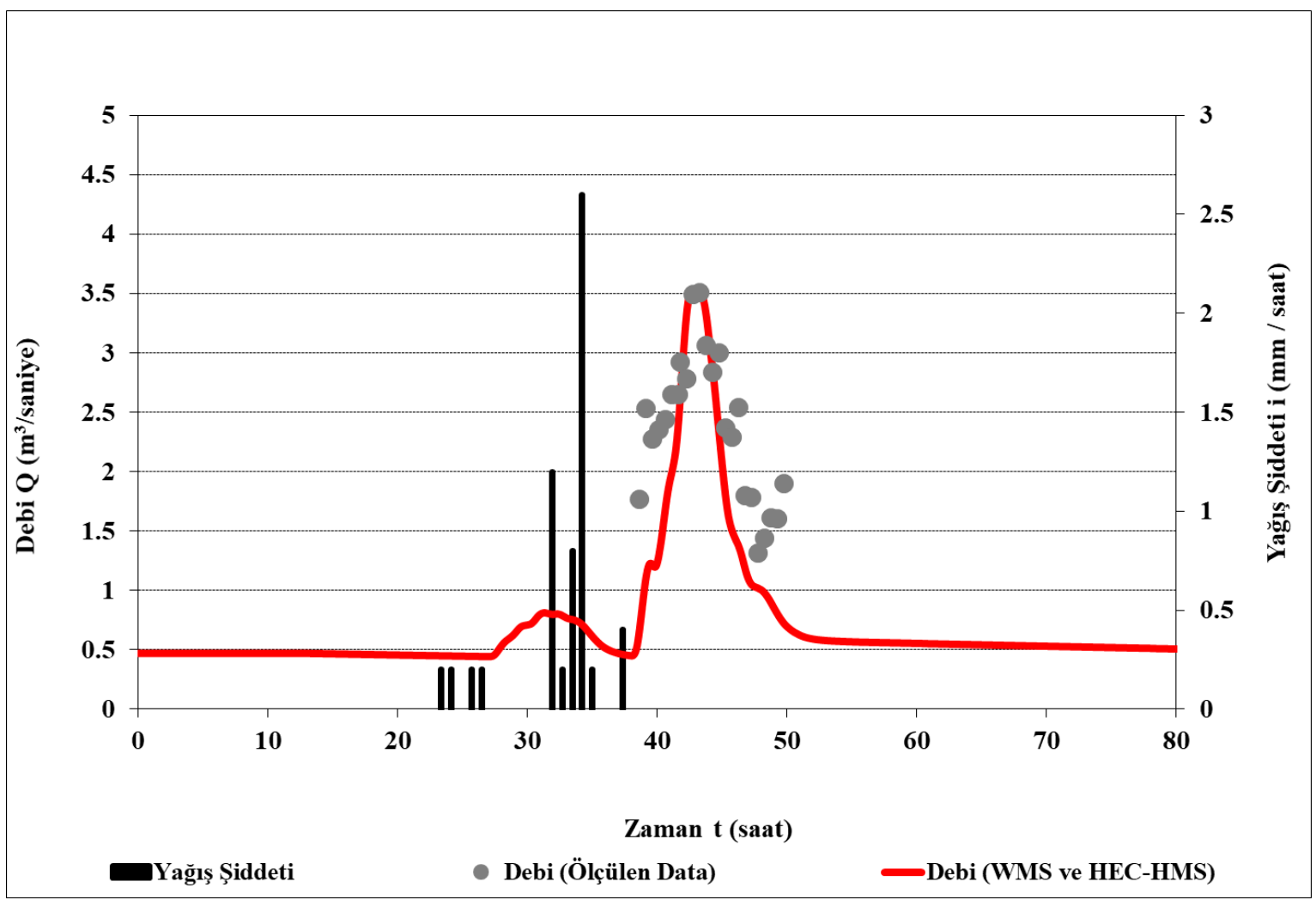

Şekil 5: 14-17 Şubat 2010 yağış serisine ait hiyetograf ve hidrograf 


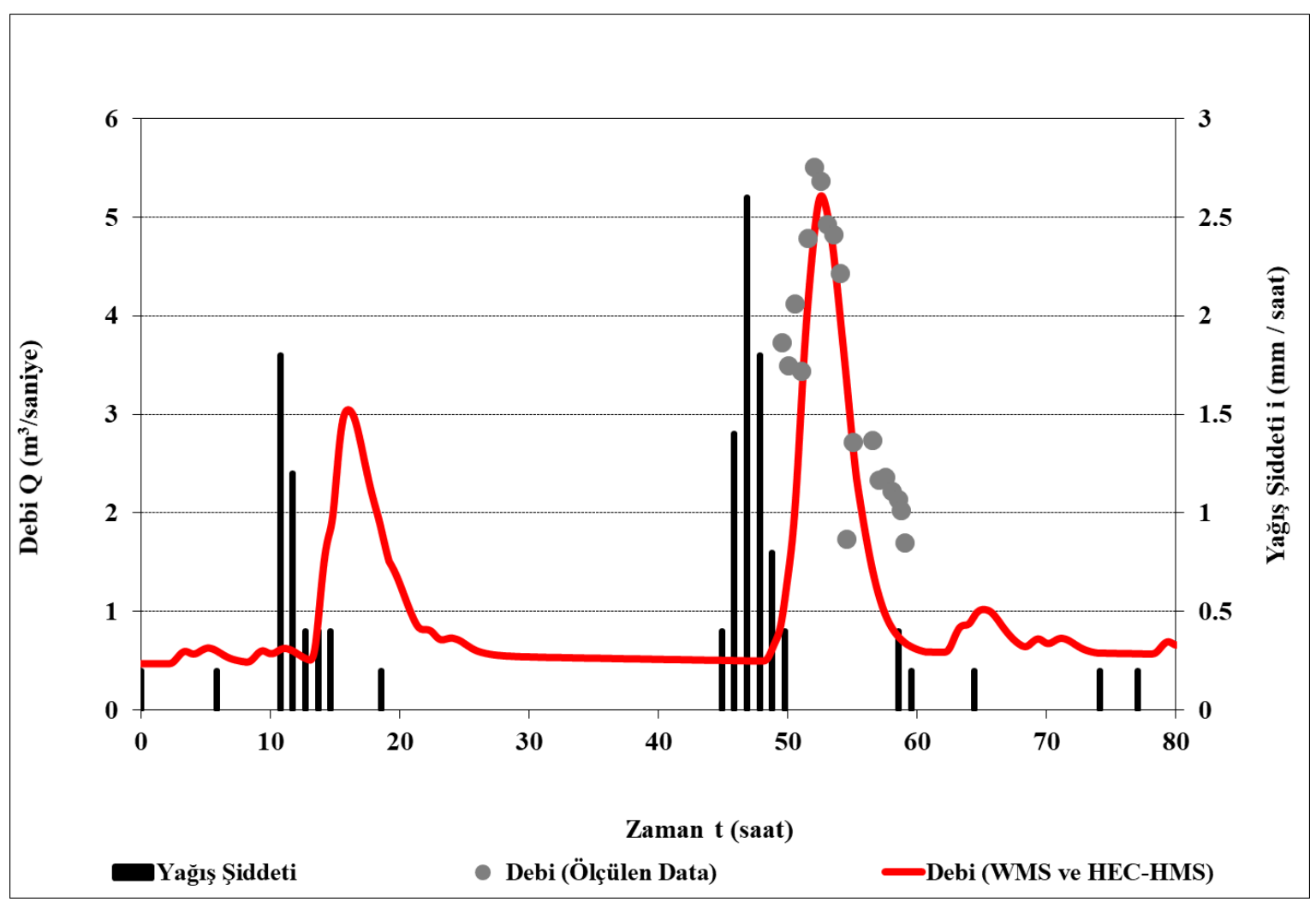

Şekil 6: 06-09 Mart 2010 yağış serisine ait hiyetograf ve hidrograf

\section{2. Şiddetli Yağışa ait Bulgular}

Çalışmanın bu bölümünde geçmiş yıllarda meydana gelen şiddetli bir yağış örnek olarak seçilmiştir. Geçmişte meydana gelen şiddetli yağışlar incelendiğinde 03-05 Temmuz 2005 tarihleri arasında meydana gelen yağış görülmüştür. Bu tarihler arasındaki yağış Meteoroloji Genel Müdürlüğü Florya Meteoroloji İstasyonu'ndan alınmış ve Şekil 7'de siyah sütunlar ile gösterilen bu hiyetograf kalibre edilmiş hidrolojik modele girilmiştir. Model sonucunda havzanın çıkış noktasında hidrograf elde edilmiştir. Elde edilen hidrograf Şekil 7'de kırmızı çizgi ile görülmektedir. Yapılan analiz sonucunda Sazlıdere Havzası'nın çıkış noktasında pik debinin $30 \mathrm{~m}^{3} / \mathrm{s}$ seviyelerine ulaştığı görülmüştür. Hidrolojik verilerin HEC-HMS programında elde edilmesi sonucunda, pik debi değeri HES-RAS programına girilmiştir. Ayrıca, geometrik veriler ile birlikte HEC-RAS hidrolik modeli çalıştırılmıştır. Programdan çıkan sonuçlar WMS programına aktarılmış ve taşkın yayılım haritası üzerinde gösterilmiştir. Daha sonra elde edilen harita "Google Earth" haritası üzerine alınarak hangi bölgelerin sular altında kalacağı tahmin edilmiştir. Taşkın yayılım haritasına bakıldığında oluşabilecek taşkının en çok hangi bölgelere zarar verdiği açıkça görülmektedir. 


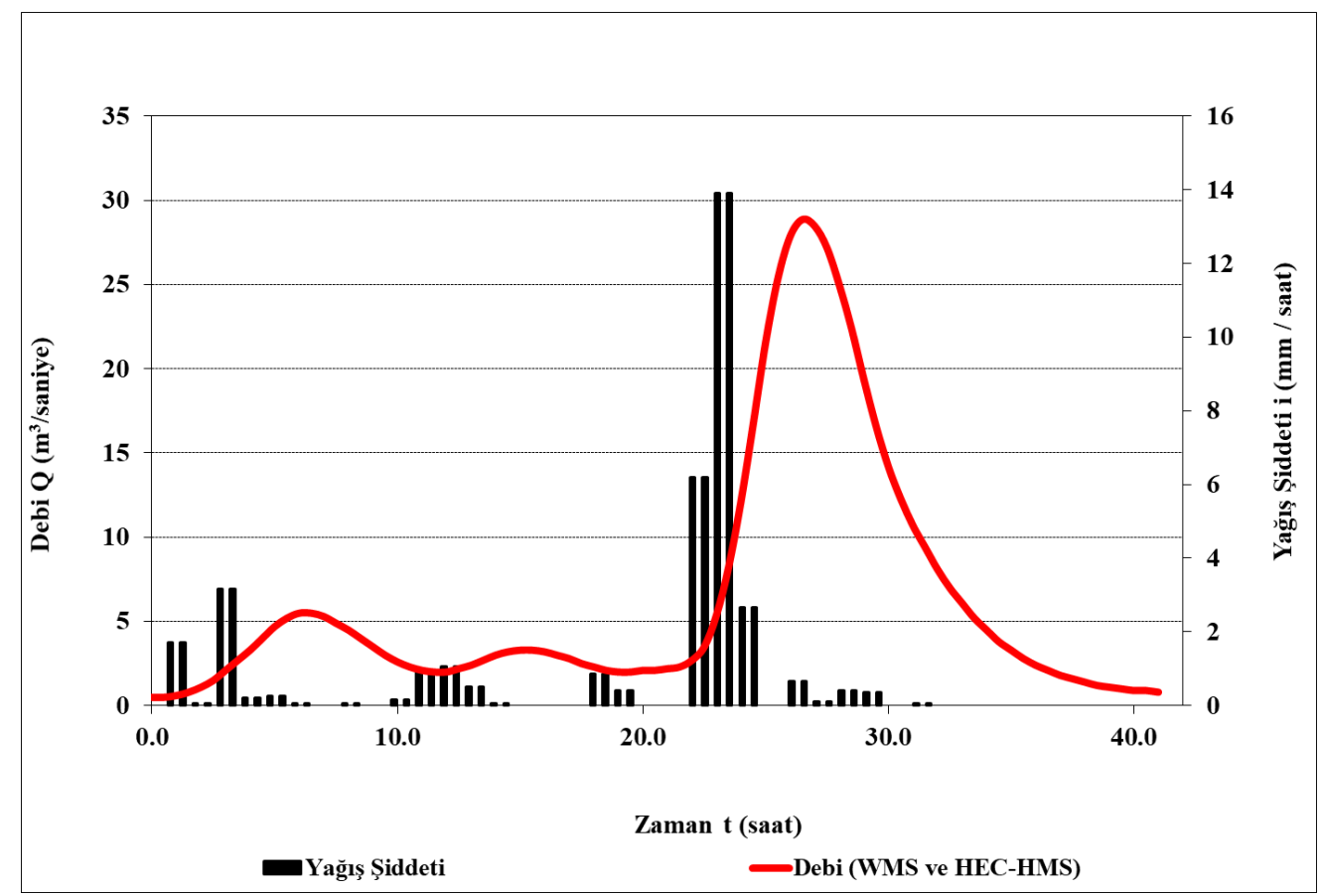

Şekil 7: 03-05 Temmuz 2005 tarihleri arasında meydana gelen yağış serisine ait hiyetograf ve hidrograf

03-05 Temmuz 2005 tarihleri arasında meydana gelen şiddetli yağıș sonrası oluşan taşkın incelendiğinde hidrolik model sonucunda elde edilen taşkın yayılım haritası Şekil 8'de görülmektedir. Elde edilen taşkın yayılım haritasına bakıldığında, hangi bölgelerin taşkın riski taşıdığı renk skalasına bakılarak anlaşılmaktadır. Skalada kırmızı renkten maviye doğru su derinliği yüksek değerlerden düşük değerlere doğru gitmektedir. Şekil 8'de görülen kırmızı renkte su yüksekliğinin maksimum 8 m civarında olabileceği öngörülmektedir. Derenin mansap bölgesinde taşkın riskinin diğer bölgelere göre fazla olduğu görülmektedir. Ayrıca, özellikle yerleşim alanlarının bulunduğu bölge kırmızı kare içerisine alınarak büyütülmüş ve bu bölgede taşkına maruz kalabilecek yerleşim alanları gösterilmiştir. Büyütülmüş taşkın yayılım haritasına bakıldığında yerleşim bölgesinden geçen ana deredeki su derinliğinin 6 m ve yayılım genişliğinin 260 m olduğu görülmektedir. Yan kolda ise yeşil ile gösterilen alanlarda deredeki su derinliğinin $4 \mathrm{~m}$ ve genişliğinin $240 \mathrm{~m}$ civarında olacağı öngörülmektedir. Bu durumda şiddetli yağış sonrasında Şekil 8'de görülen kırmızı kare içerisinde yer alan yerleşim alanlarının taşkına maruz kalacağı öngörülmektedir.

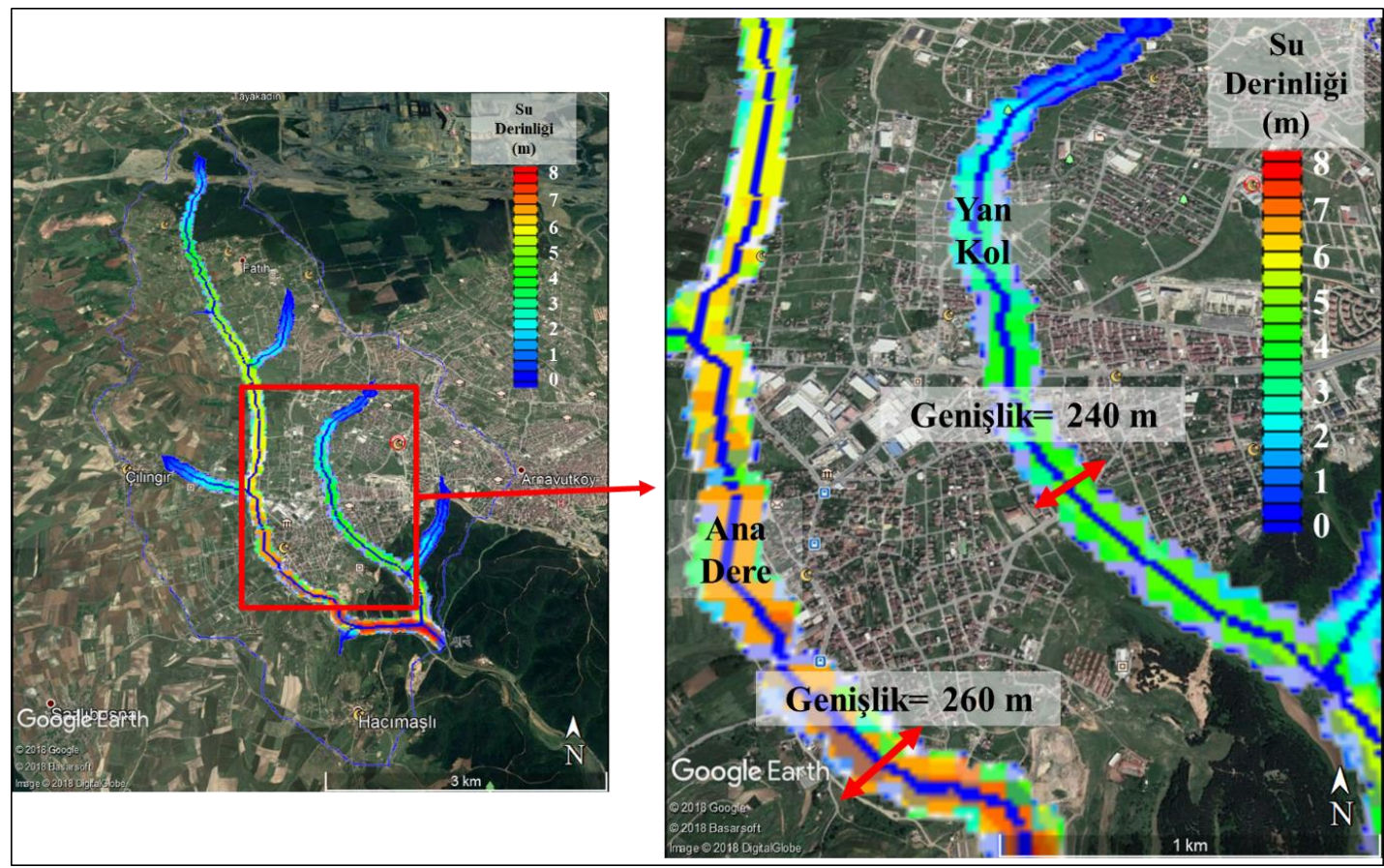

Şekil 8: Taşkın yayılım haritasının Google Earth görüntüsü üzerinde gösterilmesi 


\section{Tartışma}

Sazlıdere Havza sınırları içerisinde yer alan Türkköse Deresi ve yan kolu İstanbul İli Arnavutköy İlçesi Haraçcı Mahallesi'nin içinden geçmektedir. Dereye çok yakın mesafelerde yapıların olduğu ve bu yapıların giderek arttığı görülmektedir. Özellikle, 3. Boğaz Köprüsü bağlantı yollarının ve İstanbul Havalimanı'nın bölgede yoğun yapılaşmaya neden olacağı öngörülmektedir (Bozalioğlu 2015).Arnavutköy ilçesindeki hızlı nüfus artışına bakıldığında yapılaşmanın artacağına yönelik yapılan tahminlerin doğru olduğu sonucuna varılmaktadır. Genellikle hızlı ve kontrolsüz yapılaşma taşkın alanları göz ardı edilerek dere kenarlarına yapılmaktadır. Herhangi bir değerlendirme yapılmadan dere kenarlarına yapılan yerleşim alanları taşkın tehlikesi ile karşı karşıya kalmaktadır. Ayrıca, mevcut durumda bölgede dere kenarlarında bulunan yerleşim alanları da taşkın tehlikesi altında bulunmaktadır. Bu bölge için literatürde yapılan çalışmalar (Sönmez vd. 2012; Gülbahar 2016) incelendiğinde taşkın debisinin yüksek olduğu ve taşkın tehlikesi olduğu görülmüştür. Yerleşim alanlarının artışına yönelik baskı ve bölgedeki yüksek debiler dikkate alındığında bu bölgenin ciddi taşkın sorunu ile karşı karşıya olduğu anlaşılmaktadır. Dolayısıyla Sazlıdere Havzası içerisinde taşkın kontrolünün yapılmasına yönelik çalışmalar önem arz etmektedir.

Sel ve taşkınların engellenmesi veya neden olacağı zararların minimuma indirilmesi için taşkın kontrolünün yapılması gerekmektedir. Bu kapsamda, özellikle taşkın riski olan bölgelerde analizlerin yapılarak taşkın yataklarında oluşabilecek su derinliklerinin önceden belirlenmesinin ve gerekli uyarıların yapılabilmesi için erken uyarı sistemlerinin geliştirilmesinin gerekliliği önem arz etmektedir (Özcan 2017). Özellikle taşkın olmadan önce gerekli analizlerin yapılarak taşkın kontrolünün sağlanması hem can hem de mal kaybını önleyecek ekonomik bir çözümdür (Saral vd. 2010). Saral ve Musaoğlu (2011), taşkın kontrolünü; taşkınların vereceği zararları minimuma indirmek için yapılabilecek çalışmaların bütünü olarak tanımlamış ve taşkın kontrolü kapsamında taşkın haritalarının hazırlanmasının zararı minimize etmek için yapılacak çalışmaların başında geldiğini vurgulamıştır. Bu kapsamda, Sazlıdere Havzası'nda yapılan bu çalışma ile bu bölgede yapılacak taşkın kontrolüne yönelik çalışmalara katkı sağlanmıştır. Ayrıca, ülkemizde son yıllarda taşkın yönetimi stratejileri de dahil olmak üzere entegre su havzası yönetimi planlarının geliştirilmesi, araştırmacılar tarafından karar vericilerin uygulaması amacıyla başlatılmıştır. Orman ve Su İşleri Bakanlığı Su Yönetimi Genel Müdürlüğü tarafından hazırlanan "Taşkın Yönetimi” kitabında taşkın yayılım haritalarının önemi ve faydaları vurgulanmıştır (Kınacı vd. 2017). Kitapta, taşkın haritalarının faydaları; "1- risk değerlendirmesi ya da risk yönetimi için önem taşır, 2- belli bir noktada su seviyesinin yükselmesi durumunda erken uyarı yaparak gerekli önlemlere zemin hazırlar, 3- taşkın kurtarma operasyonlarında etkilenenlerin daha yüksek yerlere transferi için imkanlar sağlar, 4- yeni yerleşim yerlerinin planlanmasında ve oluşturulmasında fayda sağlar, 5- planlama, sulama sistemi ve su yönetimi konusunda fayda sağlar" şeklinde sıralanmıştır. Dolayısıyla bu çalışmada üretilen modeller ile oluşturulan taşkın haritası Sazlıdere Havzası içerisinde yer alan mevcut ve gelecekteki koşulları analiz etmek için kullanılabilir ve bu bölge için taşkın yönetimi planlarının geliştirilmesine hizmet edebilir.

Model aşamasında taşkın haritalarının oluşturulması için kullanılan WMS, HEC-HMS ve HEC-RAS programları daha önce Sazlıdere Havzası ile benzer özelliklere sahip diğer havzalara başarıyla uygulanmış literatürde bulunan güvenilir programlardır (Heimbur vd. 2015). Şener (2011), WMS programından yararlanarak, Ergene Nehri üzerinde bulunan Topçu alt-havzası için bir model oluşturmuştur. Özdemir (2007), yılında yaptı̆̆ı çalışmada Balıkesir ili sınırları içinde bulunan Havran Çayı havzasında meydana gelen taşkın haritalamasında HEC-RAS programını kullanmıştır. Bora ve Onuşluel Gül (2019), drenaj alanı yaklaşık 15.3 km² olan Ankara Güvenç Havzası'nda Taşkınların modellenmesi için HEC-HMS programını kullanmışlardır. Model ve ölçüm sonuçlarını karşılaştırdıklarında model sonuçlarının ölçüm sonuçları ile çok yakın olduğunu ve modelin performansının çok yüksek olduğunu görmüşlerdir. Dolayısıyla bu çalışmada literatürde güvenilir bir şekilde kullanılan WMS, HEC-HMS ve HEC-RAS programları kullanılarak taşkın kontrolüne yönelik çalışmalara katkı sağlanmıştır.

Bu çalışma kapsamında 03-05 Temmuz 2005 tarihleri arasında meydana gelen şiddetli yağış sonrası oluşan taşkın modellenmiş̧tir. Model sonucunda, Türkköse Deresi'nin Arnavutköy Haraçcı Mahallesinin içinden geçen ana ve yan kolu incelendiğinde bölgede taşkına maruz kalabilecek alanlar dikkat çekicidir. Yerleşim alanlarından geçen ana derede ve yan kolda su derinliğinin yükseldiği ve suların yerleşim alanlarına kadar yayıldığı görülmektedir. Bu durum, bölgede yer alan mevcut yerleşim alanlarının incelenmesi gerektiğini ve planlanan yerleşim alanlarının da taşkın riski dikkate alınarak yapılmasının kaçınılmaz olduğunu göstermektedir.

\section{Sonuçlar}

Yapılan bu çalışma kapsamında Sazlıdere Havzası'nın hidrolojik modeli ve Türkköse Deresi'nin hidrolik modeli oluşturulmuştur. Bu kapsamda CBS tabanlı WMS programı ile topografik harita, havza alanı, eğimi, havza sınırı ve dere güzergahları elde edilmiştir. Hidrolojik model için HEC-HMS programı ve hidrolik model için HEC-RAS programı kullanılmıştır. Daha sonra 14-17 Şubat 2010 ve 06-09 Mart 2010 yılında meydana gelen yağışş şiddetleri ve debiler kullanılarak hidrolojik modelin kalibrasyonu ve doğrulaması yapılımıştır. 3-5 Temmuz 2005 yılında meydana gelen şiddetli bir yağış verisi, kalibre edilen hidrolojik modele girilmiş̧ir. Modelden elde edilen debi değeri Türkköse Deresi için oluşturulan hidrolik modele girilmiş ve hesaplamalar yapılmıştır. Son olarak elde edilen hidrolik hesaplar WMS programına aktarılmış ve taşkın yayılım haritaları elde edilmiştir. Oluşturulan haritalar uydu görüntüsü üzerinde 
gösterilerek hangi bölgelerin taşkın riski taşıdığı belirlenmiştir. Dolayısıyla mevcut ve gelecekteki koşulları analiz ederek bu bölge için taşkın yönetimi planlarının geliştirilmesine katkı sağlayabilecek taşkın tehlike haritası elde edilmiştir. Ayrıca bu çalışma ile elde edilen detaylı sonuçlar aşağıda sıralanmıştır:

i. Taşkın riski taşıyan dere ve bölgelerin hızlı ve kolay bir şekilde modellenebilmesi için örnek bir çalışma ortaya konulmuştur. WMS, HEC-HMS ve HEC-RAS bilgisayar programları ile taşkın yayılım haritasının nasıl oluşturulduğu, taşkın derinliği ve taşkın yayılım genişliğinin nasıl elde edildiği gösterilmiştir.

ii. Sazlıdere Havzası, ormanlık arazilerin çoğunlukta olması nedeniyle henüz kentleşme ile tam olarak yüzleşmemiş ancak yapılmakta olan büyük projeler dolayısıyla, kentleşme sorunu ile karşı karşıyadır. Bu nedenle, bölgenin güncel imar planları son derece önem arz etmekte olup, havzanın hidrolojik ve hidrolik modelleri göz önünde bulundurularak yapılmalıdır. Bu çalışma ile Sazlıdere Havzası'nda yer alan Türkköse Deresi'ne ait taşkın yayılım ve su derinliği haritaları oluşturulmuştur. Oluşturulan haritalarda yerleşim alanlarının içinden geçen ana derede $6 \mathrm{~m}$ derinliğinde su yüksekliği oluştuğu ve $260 \mathrm{~m}$ genişliğinde taşkının yayıldığ 1 görülmektedir. Yan kolda da $4 \mathrm{~m}$ derinliğinde ve $240 \mathrm{~m}$ genişliğinde taşkın alanının oluştuğu görülmüştür. Böylece, kentleşme açısından tehlikeli bölgeler harita üzerinde belirlenmiştir. Dolayısıyla bölgede imar planlamasının bu veriler ışı̆̆ında yapılması önem arz etmektedir.

iii. Havzadaki yerleşimin artması ve ormanlık alanın azalmasıyla suyun tutulma oranı ve sızma miktarı azalacak ve yağışlar daha büyük oranda akışa dönüşecektir. Kısa süreli maksimum taşkın debileri, modellemede de görüldüğü gibi geniş taşkın yayılımına neden olacak ve yerleşim yerlerinin sular altında kalmasına sebebiyet verecektir. Halihazırda Arnavutköy İlçesi'ne bağlı yerleşim yeri olan, Türkköse Deresi'nin orta kısmında, dere kenarlarındaki evlerin taşkına maruz kalan alanda bulunduğu tespit edilmiştir. Taşkın tehlikesi altında olan bölgeler için çözüm önerileri geliştirilmeli ve uygulanmalidir.

\section{Teşekkür}

Bu çalışma İstanbul Üniversitesi Bilimsel Araştırma Projeleri Koordinasyon Birimi tarafından 4212 numaralı proje ile desteklenmiştir. Çalışmaya katkılarından dolayı İstanbul Üniversitesi Bilimsel Araştırma Projeleri Koordinasyon Birimi'ne teşekkür ederim. Ayrıca, makalenin incelenmesinde ve geliştirilmesinde emeği bulunan hakemlere ve editöre çok teşekkür ederim.

\section{Kaynaklar}

Akça A., (2005), Sazlıdere Havzası Su Kalitesi, Atıksu Uzaklaştırma Optimizasyonu ve Sulak Alan Maliyetlerinin Değerlendirilmesi, Yüksek Lisans Tezi, Yıldız Teknik Üniversitesi, İstanbul, Türkiye.

Apel H., Merz B., Thieken A.H., (2008), Quantification of Uncertainties in Flood Risk Assessments, International Journal of River Basin Management, 6(2), 149-162.

Ardıçlığlu M., (2017), Açık Kanal Akımları ve HEC-RAS Uygulamaları, https://docs.wixstatic.com/ugd/4045bc_995e8148557 e4f28908419ed407629b3.pdf, [Erişim 14 Eylül 2018].

Beighley R.E., Eggert K.G., Dunne T., He Y., Gummadi V., Verdin K.L., (2009), Simulating hydrologic and hydraulic processes throughout the Amazon River Basin, Hydrological Processes, 23(8), 1221-1235.

Birpınar M.E., Özkılıç N., Aktürk M.A., Mumcuoğlu H., Pirim S., Kurtuluş S., Aykırı S., Yaman M., Vardar A., Kuzlu A., Çakmak B., Akdağ B., Cihan F., Selvi G.M., Şanlımeşhur İ., Sadıkel İ., Özdoğan J., Karabulut A., Akkaş Sezgin Ö., Bukni R., Tezcan Ş., Erdoğan T., Karaaslan Y., (2006), İstanbul 2005 Yllı Il Çevre Durum Raporu, İstanbul Valiliği İl Çevre ve Orman Müdürlüğü İstanbul, Türkiye, 464ss.

Bora E., Onuşluel Gül G., (2019), Ankara Güvenç Havzası'nda Taşkınların HEC-HMS ile Modellenmesi, Türkiye Su Bilimleri ve Yönetimi Dergisi, 3(1), 44-47.

Boyraz U., Gülbaz S., Kazezyılmaz-Alhan C.M., (2013), A casestudy: Flood Analysis of Çayırova Stream in Turkey with a Hydrodynamic Model, 3. International Bursa Water Congress and Exhibition, Bursa, Türkiye, ss.826-833.

Bozalioğlu R., (2015), Ulaşım Sistemleri Uygulamalarında Arazi Kullanımından Doğan Çevre Sorunları, 2nd International Sustainable Building Symposium, 28-30 Mayıs, Ankara, Türkiye.

Cai Y., Yue W., Xu L., Yang Z., Rong Q., (2016), Sustainable urban water resources management considering life-cycle environmental impacts of water utilization under uncertainty, Resources, Conservation and Recycling, 108, 21-40.

Chen C., Huang W., (2013), Hydrological modeling of typhoon-induced extreme storm runoffs from Shihmen watershed to reservoir, Taiwan, Natural Hazards, 67(2),747-761.

Chow V.T., (1959), Open Channel Hydraulics, McGraw-HillBook Co., New York.

CORINE, (2012), Land Cover Change (LCC) 2006-2012, Version 18.5, Dataset, Date of publication: Mar 10 2016, https://land.copernicus.eu/pan-european/corine-land-cover/lcc-2006-2012/view, [Erişim 13 Aralık 2017].

Elçi Ş., Tayfur G., Haltaş İ., Kocaman B., (2017), Baraj Yıkılması Sonrası İki Boyutlu Taşkın Yayılımının Yerleşim Bölgeleri İçin Modellenmesi, İMO Teknik Dergi, 482, 7955-7975.

Elkhrancy I., (2018), Assessment and management flash flood in Najran Wady using GIS and remote sensing, Journal of the Indian Society of Remote Sensing, 45(2), 297-308.

ESDAC, (2015), Soil Data Maps, Joint Research Centre European Soil Data Centre (ESDAC), https://esdac.jrc.ec.europa.eu/resourcetype/soil-data-maps?page=1, [Erişim 13 Aralık 2017].

Gülbahar N., (2016), A Comparison Study of Some Flood Estimation Methods in terms of Design of Water Structures, International Journal of Engineering Technologies, 2 (1), 8-13. 
Gülbaz S., Kazezyılmaz-Alhan C.M., (2013), Calibrated Hydrodynamic Model for Sazlıdere Watershed in Istanbul and Investigation of Urbanization Effects, Journal of Hydrologic Engineering, 18(1), 75-84.

Hanmaiahgari P.R., Gompa N.R., Pal D., Pu J.H., (2018), Numerical modeling of the Sakuma Dam reservoir sedimentation, Natural Hazards, 91(3), 1075-1096.

Heimbur V., Hannemann J.C., Rieger W., (2015), Flood Risk Management in Remote and Impoverished Areas-A Case Study of Onaville, Haiti, Water, 7(7), 3832-3860.

Hoseinil Y., Azari A., Pilpayeh A., (2017), Flood modelling using WMS model for determining peak flood discharge in southwest Iran case study: Simili basin in Khuzestan Province, Applied Water Science, 7(6), 3355-3363.

Ibrahim N.F., Zardari N.H., Shirazi S.M., Mohd Haniffah M.R., Mat Talib, S., Yusop Z., Mohd Yusoff S.M.A., (2017), Identification of Vulnerable Areas to Floods in Kelantan River Sub-basins by using Flood Vulnerability Index, International Journal of GEOMATE, 12(29), 107-114.

Jayakrishnan R., Srinivasan R., Santhi C., Arnold J.G., (2005), Advances in the application of the SWAT model for water resources management, Hydrological Processes, 19(3), 749-762.

Khalfallah B., Saidi S., (2018), Spatiotemporal flood plain mapping and prediction using HEC-RAS - GIS tools: Case of the Mejerda river, Tunisia, Journal of African Earth Sciences, 142, 44-51.

Kınacı C., Akbaş H., Aras M., Fındık S.B., Özaltın A.M., Sakın I., Girayhan T.F., Bozkurt Hüyüktepe P., Özcan S., Yılmaz M., Yılmaz C., Doğan M., Demirel M., Altın O., Doğanay E., (2017), Taşkın Yönetimi, T.C. Orman ve Su İşleri Bakanlığı Su Yönetimi Genel Müdürlüğü, Ankara, 248ss.

Kong D., Miao C., Wu J., Borthwick A.G., Duan Q., Zhang X., (2017), Environmental impact assessments of the Xiaolangdi Reservoir on the most hyperconcentrated laden river, Yellow River, China, Environmental Science and Pollution Research, 24(5), 4337-4351.

Kömüş̧̋̈̈ A.Ü., Erkan A., Çelik S., (1998), Analysis of meteorological and terrain features leading to the Izmir flash flood, 3-4 November 1995, Natural Hazards, 18(1), 1-25.

Kömüşçü A.Ü., Çelik S., Ceylan A., (2011), 8-12 Eylül 2009 tarihlerinde marmara bölgesi’nde meydana gelen sel olayının yağış analizi, Coğrafi Bilimler Dergisi, 9(2), 209-220.

Kundzewicz Z.W., Kanae S., Seneviratne S.I., Handmer J., Nicholls N., Peduzzi P., Mechler R., Bouwer L.M., Arnell N., Mach K., Muir-Wood R., Brakenridge G.R., Kron W., Benito G., Honda Y., Takahashi K., Sherstyukov B., (2014), Flood risk and climate change: global and regional perspectives, Hydrological Sciences Journal, 59(1), 1-28.

Liu Q., Qin Y., Zhang Y., Li Z., (2015), A coupled 1D-2D hydrodynamic model for flood simulation in flood detention basin, Natural Hazards, 75(2), 1303-1325.

Logah F.Y., Amisigo A.B., Obuobie E., Kankam-Yeboah K., (2017), Flood plain hydrodynamic modelling of the Lower Volta River in Ghana, Journal of Hydrology: Regional Studies, 14, 1-9.

Mahmood Siddiqui Q.T., Hashmi H.N., Ghumman A.R., ur Rehman Mughal H., (2011), Flood Inundation Modeling for a Watershed in the Pothowar Region of Pakistan, Arabian Journal for Science and Engineering, 36(7), 1203-1220.

Moreno A.R., Fontalvo J.A.P., (2017), Hydrologic and hydraulic analysis of the Frio River Basin, Municipality of Cienaga and Zona Bananera, Magdalena Department, Logos Ciencia and Tecnologia, 9(1), 156-178.

Oğuz E., Ulupınar Y., Oğuz K., Aksoy M., Akbaş A.İ., Köse S., Çelik S., (2016a), Artvin-Hopa Bölgesinde Meydana Gelen Taşkın ve Heyelan Olayının Incelenmesi, Ulusal Heyelan Sempozyumu, 27-29 Nisan, Ankara, Türkiye.

Oğuz K., Oğuz E., Coşkun M., (2016b), Coğrafi Bilgi Sistemleri İle Taşkın Risk Alanlarının Belirlenmesi: Artvin İli Örneği, 4. Ulusal Taşkın Sempozyumu, 21-24 Kasım, Rize, Türkiye.

Özcan O., (2017), Taşkın Tespitinin Farklı Yöntemlerle Değerlendirilmesi: Ayamama Deresi Örneği, Doğal Afetler ve Çevre Dergisi, $3(1), 9-27$.

Özcan O., Saral A., Musaoğlu N., (2011), Hidrolojik Modellemenin Bilgi Difüzyon Teorisi Kullanılarak Uzaktan Algılama ve CBS İle Değerlendirilmesi, TUFUAB 2011, 23-26 Şubat, Antalya, Türkiye.

Özcan O., (2008), Sakarya Nehri Alt Havzası'nın Taşkın Risk Analizinin Uzaktan Algılama ve CBS ile Belirlenmesi, Yüksek Lisans Tezi, İstanbul Teknik Üniversitesi, İstanbul, Türkiye.

Özdemir H., (2007), Havran Çayı Havzasının (Balıkesir) CBS ve Uzaktan Algılama Yöntemleriyle Taşkın ve Heyelan Risk Analizi, Doktora Tezi, İstanbul Üniversitesi, İstanbul, Türkiye.

Patel D.P., Srivastava P.K., (2013), Flood hazards mitigation analysis using remote sensing and GIS: correspondence with town planning scheme, Water Resources Management, 27(7), 2353-2368.

Qin L., Bai X., Wang S., Zhou D., Li Y., Peng T., Tina Y., Luo G., (2015), Major problems and solutions on surface water resource utilisation in karst mountainous areas, Agricultural Water Management, 159, 55-65.

Romali N.S., Yusop Z., Ismail A.Z., (2018), Application of HEC-RAS and ArcGIS for flood plain mapping in Segamattown, Malaysia, International Journal of GEOMATE, 14(43),125-131

Saral A., Musaoğlu N., (2011), Çok Kriterli Karar Verme ve Bilgi Difüzyonu Yöntemleri ile Taşkın Risk Analizi, TMMOB Harita ve Kadastro Mühendisleri Odas1 13. Türkiye Harita Bilimsel ve Teknik Kurultayı, 18-22 Nisan, Ankara, Türkiye.

Saral A., Özcan O., Musaoglu N., (2010), Flood Risk Analysis Using Information Diffusion Theory - A Case Study Ayamama Creek, 30th EARSEL Symposium, May 31 -June 03, Paris, France.

Scharffenber W., Ely P., Daly S., Fleming M., Pak J., (2010), Hydrologic modeling system (HEC-HMS): Physically-based simulation components, 2nd Joint Federal Interagency Conference, June 27-July 1, Las Vegas, NV, USA., ss.1-8.

SCS, (1975), Urban hydrology for small watersheds, tech. Rel. No. 55, U.S. Dept. of Agriculture, Washington D.C.

Skhakhfa I.D., Ouerdachi L., (2016), Hydrological modelling of wadi Ressoul watershed, Algeria, by HECHMS model, Journal of Water and Land Development, 31 (X-XII), 139-147.

Soliman M.M., El Tahran A.H.M.H., Taher A.H., Khadr W.M.H., (2015), Hydrological Analysis and Flood Mitigation at Wadi Hadramawt, Yemen, Arabian Journal of Geosciences, 8(11), 10169-10180.

Sönmez O., Öztürk M., Doğan E., (2012), İstanbul Derelerinin Taşkın Debilerinin Tahmini, Sakarya Üniversitesi Fen Bilimleri Enstitüsü Dergisi, 16(2), 130-135. 
Subyani A.M., (2011), Hydrologic behavior and flood probability for selected arid basins in Makkaharea, western Saudi Arabia, Arabian Journal of Geosciences, 4(5-6), 817-824.

Şen Z., Khiyami H.A., Al-Harthy S.G., Al Ammawi F.A., Al-Balkhi A.B., Al-Zahrani M.I., Al Hawsawy H.M., (2013), Flash flood inundation map preparation for Wadis in arid regions, Arabian Journal of Geosciences, 6(9), 3563- 3572.

Şener M., (2012), Determination of basin characteristics by using geographical information systems (GIS), Journal of Environmental Protection and Ecology, 12(4), 1941-1947.

Uddin K., Gurung D.R, Giriraj A., Shrestha A., (2013), Application of Remote Sensing and GIS for Flood Hazard Management: A Case Study from Sindh Province, Pakistan, American Journal of Geographic Information System, 2(1), 1-5. 